\title{
Are All Buildings Architecture?
}

\author{
Oluwadamilola Ajoke Alabi * Adewale Segun Alabi \\ Department of Architecture, Bells University of Technology, Ota, Nigeria, Km 8, Idiroko Road, Benja Village, \\ P.M.B. 1015, Ota, Ogun State, Nigeria
}

\begin{abstract}
A universal definition of a building is "a permanent structure which provides, shelter, encloses space and can be occupied by animals, persons, goods and services". However, there is debate on whether all buildings can be architecture. This study is a metaphysical discussion on the answers to this question. Analytic philosophy is used in the study to propose logical arguments from perspectives of definitions and method of analysis of architecture and buildings. The conclusion of the discussion reveals that architecture goes beyond building by expressing a deeper feeling with venustas inclination.
\end{abstract}

Keywords: buildings, architecture, analytic philosophy, metaphysics

DOI: $10.7176 / \mathrm{ADS} / 82-01$

Publication date:May $31^{\text {st }} 2020$

\section{Introduction}

Many students of architecture believe that once a building is designed, it is automatically a piece of architecture. Practicing architects and some architectural educators are not left out of this misguided opinion. The question of whether all buildings can be called architecture is an historic question. Attempts have been made to give an answer. This discussion uses analytical philosophy to logically attempt an answer. Analytical philosophy also known as analytic philosophy is a $20^{\text {th }}$ century movement led by Bertrand Russell (1872-1970), Afred North Whitehead (1861-1947), George Edward Moore (1873-1958), and Ludwig Wittgenstein (1911-1951) who objected conceptual analysis based on new developments in Logic. Thus, the question 'are all buildings architecture?' will be answered using logical techniques to analyse standard definitions as well as methods of analysis of buildings and architecture.

\section{Logical argument from the perspective of the standard definitions of building and architecture}

According to Jokiniemi and Davies, (2008), a building is defined as "any permanent structure which provides shelter, encloses space and can be occupied by people, animals, goods or services. This definition discusses the function and the usefulness of the structure and this can be clearly assumed from the definition. Thus, in simple terms any building that meets these criteria can be said to be a building but if such building transcends beyond just a building and communicate with some level of intellectual understanding then such can be classified as something else.

The same dictionary defines architecture as "the art and science of producing built form, the product and study of this", thus indicating architecture as an intention. Architecture has its goals and aspirations directed at meeting the clients' and users' needs by serving them as best as possible in a way to improve physical \& mental health, safety and pleasure in life (Jacobson \& Brock, 2014). According to Unwin (2003) and Unwin (2014), architecture is the determination by which a mind gives intellectual structure to a building, a place, a garden, a city, etc. Consequently, the architecture of a building is the underlying intellectual structure that has given it form. Building by distinction, is the performance of physical realization and a building the product. The process of construction can be understood as a translation from abstract to actual (Sweeting, 2011). In other words, architecture is the contribution of the mind in terms of intellectual entities which can result to building, while building can be said to be the physical realization of architecture which come to play in constructional process. These definitions make building and architecture to stand alone and can be related if it achieves the conceptual links. In other words, not all buildings are architecture except that building which meets some intellectual creation of architecture. Buildings that are not works of architecture converse at a much less expression and therefore necessarily more vague level. Whereas when we link communication with intellectual understanding, architecture operates at a different (deeper) level (Sweeting, 2011).

\section{Logical Argument from the Perspective of the Method of Analysis of Buildings \& Architecture}

The last 200 years of architectural education and theory have generated dramatically different and rapidly changing concepts of what constitutes good architecture (Jacobson and Brock, 2014). Architecture serves the people who want to build buildings as well as the people who use them and in extension the onlooker or passer-by who admires the aesthetic. There must be a level of adequacy and performance that the building must attain. This sense of service to society builds on the deeper purpose makes architecture the vital human endeavour that it is. Architecture aspires to a higher level of satisfaction than mere building (Jacobson and Brock, 2014). 
Vitruvius' triumvirate of firmitas, utilitas, and venustas (Unwin, 2014), gives a clearer picture of how buildings must meet or satisfy these three interrelated goals to be firm in its physical structure, to be useful in its design, and to be beautiful respectively which gives architecture's goals and aspirations illumination, greater insights and understanding, that cut across ages, periods, styles, and fashion.

All buildings merely serve functions of firmitas and utilitas while buildings which are works of architecture jointly serve the functions of "firmitas, utilitas and venustas" (Vitruvius, Translated 1914). This is the centre of what architecture aims at and if the three functions are achieved successfully, the building becomes a distinct work of architecture. The primary function of a building is usefulness (utilitas) followed by durability/structural integrity (firmitas). In order to determine the integrity of a building, these two functions are critically analysed. However, the analysis of a work of architecture goes beyond the assessment of utilitas and firmitas and delves into the understanding of its beauty (venustas). Jacobson \& Brock (2014) describe the notion of venustas as 'not only the beauty of form but other related qualities that can generate interest, pleasurable memories, humour, intellectual challenge and when appropriate, sorrow. Therefore, architecture is assessed based on its elements, conditions affecting it and attitudes that may be adopted in doing it (Unwin, 1997; Unwin, 2003; Unwin, 2009; and Unwin, 2014) unlike buildings.

\section{Conclusion}

The difference between a building and a piece of architecture is that a building has a function and must be designed with safety in mind among many other comfort and satisfaction needs. To this end, the dictionary meaning of architecture as an art and science is captured by Frank Lloyd Wright's words "Beautiful buildings are true organisms, spiritually conceived works of art using the best technology by inspiration!"

\section{References}

Sweeting, B. (2011), "Conversing with Drawings and Buildings: From Abstract to Actual in Architecture", Kybernetes, 40 (7/8), Emerald Insight, 1159-1165.

Davies, N. \& Jokiniemi, E. (2008), The Dictionary of Architecture and Building Construction, Routledge.

Jacobson, M. \& Brock, S. (2014), Invitation to Architecture: Discovering Delight in the World Built Around Us, The Taunton Press, Inc. Newtown, CT.

Scruton, R. (1979), The Aesthetics of Architecture. Princeton University Press.

Unwin, S. (2007), Analysing Architecture Through Drawing, Building Research \& Information, 35(1), Taylor \& Francis, 101-110.

Unwin, S. (1997). Analysing Architecture. London: Routledge.

Unwin, S. (2003). Analysing Architecture. 2nd edition. London: Routledge.

Unwin, S. (2009). Analysing Architecture. 3rd edition. London: Routledge.

Unwin, S. (2014). Analysing Architecture. 4th edition. India: Taylor \& Francis.

Vitruvius (Translated 1914). Ten Books on Architecture. London: Humphrey Milford Oxford Press. 